\title{
Synthesis, spectroscopic studies of novel N-substituted phthalimides and evaluation of their antibacterial, antioxidant, DNA binding and molecular docking studies
}

\author{
Pattan Sirajuddin Nayab', Madhusudana Pulaganti², Suresh Kumar Chitta², \\ Mohammad Oves ${ }^{3}$ and Rahisuddin ${ }^{1}$
}

${ }^{1}$ Department of Chemistry, Jamia Millia Islamia, New Delhi 110 025. India; ${ }^{2}$ Department of Biochemistry, Sri Krishnadevraya University, Ananthapuram 515 003. India; ${ }^{3}$ Department of Agricultural Microbiology, Aligarh Muslim University, Aligarh 202 002, India.

\begin{tabular}{|c|c|}
\hline \multicolumn{2}{|l|}{ Article Info } \\
\hline $\begin{array}{l}\text { Received: } \\
\text { Accepted: } \\
\text { Available Online: }\end{array}$ & $\begin{array}{r}11 \text { June } 2015 \\
30 \text { June } 2015 \\
17 \text { August } 2015\end{array}$ \\
\hline DOI: $10.3329 /$ bjp.v & i3.23637 \\
\hline $\begin{array}{l}\text { Cite this article: } \\
\text { Nayab PS, Pulaga } \\
\text { Oves M, Uddin R. } \\
\text { scopic studies of n } \\
\text { phthalimides and } \\
\text { antibacterial, antios } \\
\text { ing and molecular } \\
\text { Bangladesh J Pharn } \\
-13 \text {. }\end{array}$ & $\begin{array}{l}\text { M, Chitta SK, } \\
\text { nthesis, spectro- } \\
\text { el N-substituted } \\
\text { aluation of their } \\
\text { lant, DNA bind- } \\
\text { docking studies. } \\
\text { col. 2015; 10: } 703\end{array}$ \\
\hline
\end{tabular}

\begin{abstract}
A new series of $\mathrm{N}$-substituted phthalimide derivatives were prepared by condensation of appropriate amount of $n$-amino tetrachlorophthalimide with respective aldehyde in glacial acetic acid. The structural investigation of the synthesized compounds was done by spectroscopic methods (UV-Vis., IR, ${ }^{1} \mathrm{H}$ and ${ }^{13} \mathrm{C} \mathrm{NMR}$ ) and elemental analysis. The antibacterial screening of these compounds was performed against Escherichia coli and Staphylococcus mutans. The synthesized compounds were evaluated for their antioxidant potential using 2,2-diphenyl-1-picrylhydrazyl (DPPH) as a scavenging agent. The interaction ability of most promising compounds ( $\mathbf{3 a}$ and $\mathbf{3 b}$ ) with native calf thymus DNA (Ct-DNA) was also studied by means of UV-Vis., circular dichroism (CD), viscosity measurements and thermal studies. The intrinsic binding constants $\left(\mathrm{K}_{\mathrm{b}}\right)$ of $\mathbf{3 a}$ and $\mathbf{3} \mathbf{b}$ with Ct-DNA obtained from UV-Vis. absorption studies were $8 \times 10^{4}$ and $1 \times 10^{5}$, respectively. Molecular docking of target compounds (3a and $\mathbf{3 b})$ against DNA dodecamer $\mathrm{d}$ (CGCGAATTCGCG) ${ }_{2}$ has been carried out. The test compounds exhibited remarkable antibacterial, antioxidant and DNA binding activities.
\end{abstract}

\section{Introduction}

Phthalimides have attracted tremendous attention in the field of medicinal chemistry owing to their promising bioactivities such as anti-tumor (Chan et al., 1987), antimicrobial (Bansode et al., 2009), anti-inflammatory (Lima et al., 2002) and DNA cleaving activities (Abdel-Aziz, 2007). The molecules contain a phthalimide ring, could easily interact with various active targets in biological system because of their hydrophobicity. Various DNA-targeting drugs are currently available as approved antimicrobial drugs. However, significant adverse effects and clinical costs related to these drugs have stimulated the search for new antimicrobial agents. The activity of phthalimides as antibacterial drugs may be mainly attributed to the inhibi- tion of DNA replication. Therefore, the study of interaction of phthalimides with Ct-DNA is considered of great importance for investigation of their potential antimicrobial activities.

Since the interaction of drugs led to conformational changes in the structure of protein, investigating the interactions of drug with protein is a critical step in the rational drug discovery. The molecular docking approach can be used for understanding the intermolecular interactions between proteins and ligands (Huang and Zou, 2010). Many studies have been investigated regarding the biological activities of Schiff bases including their anticancer (Shukla et al., 2013), antimicrobial (Tumer et al., 2006) and antifungal (Tumer et al., 1999) activities. The biological activities of phthalimide ana- 
logues have been paid more attention long before, however, the antimicrobial activity of phthalimide linked to Schiff bases have few been reported (Al-Azzawi and Al-Razzak, 2014). Phthalimide moiety conjugated with azomethine group may have elevated affinity for cancer cells. Bearing these facts in mind, we set out to develop novel Schiff bases linked to phthalimide pharmacopore.

\section{Materials and Methods}

\section{Chemicals and equipments}

All reagents were used as purchased from SigmaAldrich. The solvents were of spectroscopy grade and used without further treatment. The reactions were monitored by thin layer chromatography using UV cabinet for visualization. Yield percent was of purified product and was not optimized. Melting point was recorded using an electrothermal melting point apparatus and were uncorrected. Elemental analysis was carried out on a Vario-Micro elemental analyzer. Electronic spectra were obtained on a Perkin Elmer Lamda 40 UV-Visible spectrophotometer. IR spectra were recorded in the range of $4000-400 \mathrm{~cm}^{-1}$ on a Perkin Elmer Spectrum RXI IR Instrument as $\mathrm{KBr}$ discs. ${ }^{1} \mathrm{H}$ NMR spectra were recorded on Bruker DPX-300 NMR spectrometer operating at $300 \mathrm{MHz}$ using DMSO- $\mathrm{d}_{6}$ as solvent. ${ }^{13} \mathrm{C}$ NMR spectra were recorded on AgilentNMR-vnmrs 500 spectrometer. Fluorescence spectra were obtained on Jobin-Yvon Fluorolog 3-22 spectrofluorometer using $450 \mathrm{~W}$ xenon lamp and R928P PMT as the excitation source and detector, respectively. CD spectra were obtained on a Chirascan CD spectropolarimeter.

\section{Synthesis}

The title compounds were synthesized by the condensation reaction of $n$-aminotetrachloro phthalimide with respective aldehyde (Scheme 1). All spectral data were agreed well with the synthesized Schiff base phthalimide derivatives.

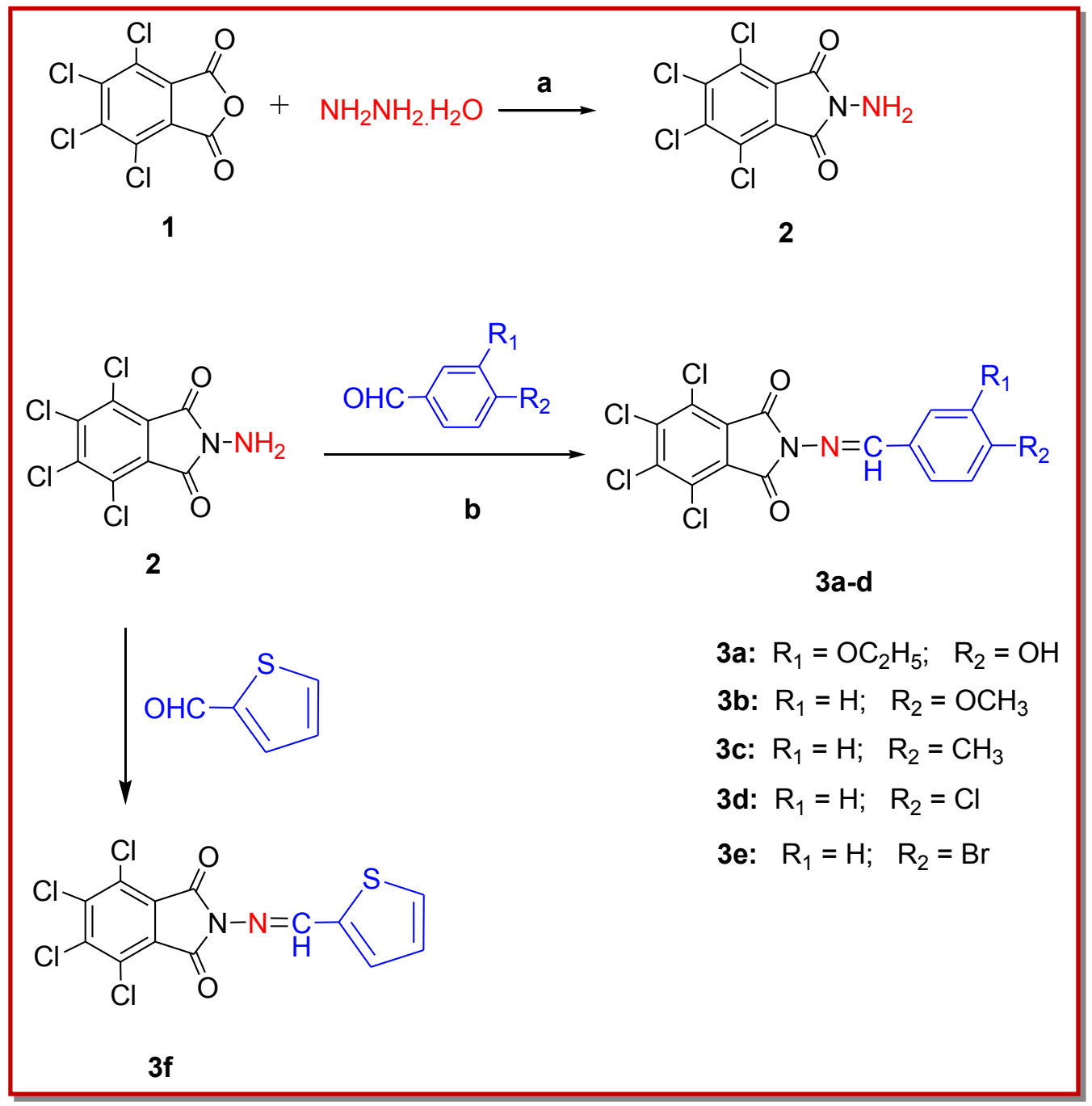

Scheme I: Reagents and conditions: (a) ethanol/ water, reflux, 2 hours; (b) glacial acetic acid, ethanol, reflux, 6-8 hours 
2-Amino-4,5,6,7-tetrachloroisoindoline-1,3-dione (2): 2Amino-4,5,6,7-tetrachloroisoindoline-1,3-dione (2) has been synthesized according to previous report (Nayab et al., 2015).

General procedure for the synthesis of compounds (3a3f)

n-Amino tetrachlorophthalimide $(0.598 \mathrm{~g}, 2 \mathrm{mmol})$ was suspended in boiling glacial acetic acid, followed by the addition of solution of appropriate aldehyde $(2 \mathrm{mmol})$ in ethanol and the reaction mixture refluxed with stiring for 6-8 hours. After cooling the solution, the resulting colored precipitates were filtered, washed with cold ethanol. Finally the compounds dried in vacuum desiccator over fused calcium chloride.

2-(3-Ethoxy-4-hydroxybenzylideneamino) - 4, 5, 6, 7tetrachloroisoindoline-1,3-dione (3a): Yellow solid; Yield 75\%; m.p: $230^{\circ} \mathrm{C}$. UV $\lambda_{\max }(\mathrm{nm}): 320,267$. IR $v_{\max }\left(\mathrm{cm}^{-1}\right)$ : 3087 v(OH); 1784, 1726, v(C=O); 1592 v(C=N); 740 v(Ar); ${ }^{1} \mathrm{H}$ NMR $\left(300 \mathrm{MHz}, \mathrm{DMSO}-\mathrm{d}_{6}\right) \delta$ in ppm: 9.746 (s, 1H, $\mathrm{OH}) ; 8.89$ (s, 1H, -CH=N); 8.009 (s, 1H,- Ar-H); 7.300$7.443(\mathrm{~m}, 1 \mathrm{H},-\mathrm{Ar}-\mathrm{H})$; 6.942-6.969 (d, 1H, J=8.1Hz, Ar$\mathrm{H}) ; 3.989-4.100\left(\mathrm{q}, 2 \mathrm{H}, \mathrm{J}=6.6 \mathrm{~Hz},-\mathrm{OCH}_{2}\right) ; 1.369-1.391(\mathrm{t}$, $\left.3 \mathrm{H}, \mathrm{J}=1.8 \mathrm{~Hz},-\mathrm{CH}_{3}\right) .{ }^{13} \mathrm{C} \mathrm{NMR}\left(100 \mathrm{MHz}, \mathrm{DMSO}-\mathrm{d}_{6}\right) \delta$ in ppm: $163.07 ; 162.40 ; 159.66 ; 159.47 ; 149.63 ; 138.81$; 134.87; 130.43; 129.34; 124.87; 117.07; 115.13; 56.00; 20.58. Anal. Calcd. for $\mathrm{C}_{17} \mathrm{H}_{10} \mathrm{Cl}_{4} \mathrm{~N}_{2} \mathrm{O}_{4}$ (448.08): C, 45.57; $\mathrm{H}$, $2.25 ; \mathrm{N}, 6.25$. Found: C, 45.61; H, 2.30; N, 6.19.

2-(4-Methoxybenzylideneamino)-4,5,6,7-tetrachloroisoindoline-1,3-dione (3b): Brown solid; Yield 68\%; m.p: $238^{\circ} \mathrm{C}$. UV $\lambda_{\max }(\mathrm{nm}): 322,295$. IR $v_{\max }\left(\mathrm{cm}^{-1}\right): 1782,1734 \mathrm{v}$ $(\mathrm{C}=\mathrm{O}) ; 1541 \mathrm{v}(\mathrm{C}=\mathrm{N}) ; 715 \mathrm{v}(\mathrm{Ar}-\mathrm{H}) .{ }^{1} \mathrm{H}$ NMR $(300 \mathrm{MHz}$, DMSO-d 6 ) $\delta$ in ppm: 9.025 (s, 1H, N=CH-); 7.835-7.861 $(\mathrm{d}, 2 \mathrm{H}, \mathrm{J}=7.8 \mathrm{~Hz}, \mathrm{Ar}-\mathrm{H})$; 7.078-7.105 (d, 2H, J = 8.1 Hz, Ar-H); 3.821 (s, 3H, $\left.-\mathrm{OCH}_{3}\right) .{ }^{13} \mathrm{C}$ NMR (100 MHz, DMSO $\left.-\mathrm{d}_{6}\right) \delta$ in ppm: $163.21 ; 162.64 ; 150.68 ; 146.40 ; 138.72$; 133.21; 130.41; 129.36; 127.59; 116.16; 56.63; Anal. Calcd. For $\mathrm{C}_{16} \mathrm{H}_{8} \mathrm{Cl}_{4} \mathrm{~N}_{2} \mathrm{O}_{3}$ (418.06): C, 45.97; $\mathrm{H}, 1.93 ; \mathrm{N}, 6.70$. Found: C, 46.02; H, 1.96; N, 6.65.

2-(4-methylbenzylideneamino)-4,5,6,7-tetrachloroisoindoline -1,3-dione (3c): Yellow solid; Yield $76 \%$; m.p: $242^{\circ} \mathrm{C}$. UV $\lambda_{\max }(\mathrm{nm}): 349,279 . \mathrm{IR} v_{\max }\left(\mathrm{cm}^{-1}\right): 2972,2958 \mathrm{v}(\mathrm{C}-\mathrm{H})$; 1786, $1737 v(\mathrm{C}=\mathrm{O}) ; 1583 \mathrm{v}(\mathrm{C}=\mathrm{N}) ; 711 \mathrm{v}(\mathrm{Ar}-\mathrm{H}) .{ }^{1} \mathrm{H}$ NMR (300 MHz, DMSO-d 6 ) $\delta$ in ppm: $9.11(\mathrm{~s}, 1 \mathrm{H}, \mathrm{N}=\mathrm{CH})$; 7.34-7.80 (m, 4H, Ar-H); 2.39 (s, 3H, $\left.\mathrm{CH}_{3}\right) .{ }^{13} \mathrm{C}$ NMR (100 $\left.\mathrm{MHz}, \mathrm{DMSO}-\mathrm{d}_{6}\right) \delta$ in ppm: $163.42 ; 162.17 ; 148.40$; 141.28; 137.81; 133.67; 130.28; 129.34; 129.18; 128.89; 23.83; Anal. Calcd. For $\mathrm{C}_{16} \mathrm{H}_{8} \mathrm{Cl}_{4} \mathrm{~N}_{2} \mathrm{O}_{2}$ (402.06): C, 47.80; H, 2.01; N, 6.97. Found: C, 47.85; H, 1.98; N, 6.92 .

2-(4-Chlorobenzylideneamino)-4,5,6,7-tetrachloroisoindoline1,3-dione (3d): Pale yellow solid; Yield $62 \%$; $\mathrm{mp}:>300^{\circ} \mathrm{C}$; UV $\lambda_{\max }(\mathrm{nm}): 328,292 ; \mathrm{IR} v_{\max }\left(\mathrm{cm}^{-1}\right): 1790,1719 v(\mathrm{C}=\mathrm{O})$, $1588 v(\mathrm{C}=\mathrm{N}), 737 \mathrm{v}(\mathrm{Ar}) ;{ }^{1} \mathrm{H}$ NMR (300 MHz, DMSO-d 6 ) $\delta$ in ppm: $9.263(\mathrm{~s}, 1 \mathrm{H}, \mathrm{N}=\mathrm{CH}), 7.933-7.962(\mathrm{~d}, 2 \mathrm{H}, \mathrm{J}=8.7$ $\mathrm{Hz}$ Ar-H), 7.617-7.645 (d, 2H, J = 8.4 Hz Ar-H); ${ }^{13} \mathrm{C}$ NMR (100 MHz, DMSO-d $\left.{ }_{6}\right) \delta$ in ppm: 163.06, 162.18,
149.27, 138.84, 137.12, 133.18, 130.96,130.37, 129.78, 128.37; Anal. calcd. for $\mathrm{C}_{15} \mathrm{H}_{5} \mathrm{Cl}_{5} \mathrm{~N}_{2} \mathrm{O}_{2}$ (422.98): C, 42.64; H, 1.19; N, 6.63. Found: C, 42.68; H, 1.26; N, 6.65.

2-(4-Bromobenzylideneamino)-4,5,6,7-tetrachloroisoindoline1,3-dione (3e): Brown solid; Yield $66 \%$; mp: $>300^{\circ} \mathrm{C}$; UV $\lambda_{\max }(\mathrm{nm}): 333,280$; IR $v_{\max }\left(\mathrm{cm}^{-1}\right): 1775,1709 v(\mathrm{C}=\mathrm{O})$, $1585 \mathrm{v}(\mathrm{C}=\mathrm{N}), 706 \mathrm{v}(\mathrm{Ar}) ;{ }^{1} \mathrm{H}$ NMR $\left(300 \mathrm{MHz}, \mathrm{DMSO}_{-} \mathrm{d}_{6}\right)$ $\delta$ in ppm: $8.876(\mathrm{~s}, 1 \mathrm{H}, \mathrm{N}=\mathrm{CH}), 7.452-7.574(\mathrm{~m}, 4 \mathrm{H}, \mathrm{Ar}-$ $\mathrm{H}) ;{ }^{13} \mathrm{C}$ NMR $\left(100 \mathrm{MHz}, \mathrm{DMSO}-\mathrm{d}_{6}\right) \delta$ in ppm: $163.12,162.44,149.71,138.21,133.69,132.18,130.92$, 129.98, 128.26, 127.40, Anal. calcd. for $\mathrm{C}_{15} \mathrm{H}_{5} \mathrm{BrCl}_{4} \mathrm{~N}_{2} \mathrm{O}_{2}$ (466.93): C, 38.58; H, 1.08; N, 6.00. Found: C, 38.54; H, $1.10 ; \mathrm{N}, 6.04$.

2-(Thiophen-2-ylmethyleneamino)-4,5,6,7-tetrachloroisoindoline-1,3-dione (3f): Pale Yellow solid; Yield 81\%; m.p: $268^{\circ} \mathrm{C}$. UV $\lambda_{\max }(\mathrm{nm}): 278,318$. IR $v_{\max }\left(\mathrm{cm}^{-1}\right): 1758$, $1700 v(\mathrm{C}=\mathrm{O}) ; 1594 \mathrm{v}(\mathrm{C}=\mathrm{N}) ; 737 \mathrm{v}(\mathrm{Ar}) .{ }^{1} \mathrm{H}$ NMR $(300$ $\left.\mathrm{MHz}, \mathrm{DMSO}-\mathrm{d}_{6}\right) \delta$ in ppm: $9.34(\mathrm{~s}, 1 \mathrm{H}, \mathrm{N}=\mathrm{CH})$; 7.247.91 (m, 3H, Ar-H); ${ }^{13} \mathrm{C}$ NMR (100 MHz, DMSO-d 6 ) $\delta$ in ppm:164.82, 163.75, 139.63, 139.33, 138.81, 132.82, 128.37, 127.04, 127.60, 125.84. Anal. Calcd. For $\mathrm{C}_{13} \mathrm{H}_{4} \mathrm{Cl}_{4} \mathrm{~N}_{2} \mathrm{O}_{2} \mathrm{~S}$ (394.06): C, 39.62; H, 1.02; N, 7.11; S, 8.14. Found: C, 39.57; H, 1.09; N, 7.05; S, 8.10.

\section{Antibacterial screening}

Antibacterial activity of all the compounds was determined against E. coli (MTCC-739) and S. mutans (MTCC-737), by standard micro broth dilution assay as per NCCLS protocol. MIC determination was planned using a micro dilution assay according to the Clinical and Laboratory Standards Institute. The bacteria were freshly cultivated in Mueller Hinton broth at $37^{\circ} \mathrm{C}$ in an incubator for 24 hours and added to a 96-well plate at a final concentration of $1.0 \times 10^{5}(\mathrm{CFU} / \mathrm{mL})$. A serial twofold dilution pattern was set in the medium wells with concentration of compounds ranging from 1000 to $7.8125 \mu \mathrm{g} / \mathrm{mL}$. A number of incongruent serial dilutions in $\mu \mathrm{g} / \mathrm{mL}$ were added to each well. DMSO (10\%) with no growth inhibition of bacteria in the medium well was taken as the negative control. The least concentration of the drug, showing complete inhibition (i.e. no turbidity in the medium wells of the visible growth after 24 hours of incubation at $37^{\circ} \mathrm{C}$, represented as the MIC. Following 24 hours, $100 \mu \mathrm{L}$ portions were taken from the wells, serially diluted and then spotted onto Mueller Hinton agar plates. The plates were observed for overnight incubation at $37^{\circ} \mathrm{C}$. To assess the legitimacy and precision of the results all assays were carried out in triplicate.

\section{Antioxidant activity}

The synthesized compounds were also evaluated for their antioxidant activity using 2,2-diphenyl-1-picrylhydrazyl (DPPH) as a scavenging agent. The scavenging activity was performed according to methodology described previously (Miliauskas et al., 2004). To the solution of $3 \mathrm{~mL}$ of $0.1 \mathrm{mM} \mathrm{DPPH} \cdot$ (2,2-diphenyl-2- 
picrylhydrazyl) in methanol, $100 \mu \mathrm{L}$ of samples (0.6-1.4 $\mathrm{mg} / \mathrm{mL}$ in ethanol) or ascorbic acid (standard) (0.1-0.8 $\mathrm{mg} / \mathrm{mL}$ ) was added and the reaction mixture was incubated at $37^{\circ} \mathrm{C}$ for $30 \mathrm{~min}$ on water bath. The ability of samples to scavenge DPPH radical was assessed by observing the decrease in absorbance at $517 \mathrm{~nm}$ using UV-Vis. spectrophotometer. The \%inhibition was calculated using the following relation:

$$
\% \text { Inhibition }=\frac{\mathrm{A}_{\text {Control }}-\mathrm{A}_{\text {Sample }}}{\mathrm{A}_{\text {Control }}} \times 100
$$

Where $\mathrm{A}_{\text {Control }}=$ absorbance of $\mathrm{DPPH} \bullet$ in methanol without an antioxidant and A $_{\text {Sample }}=$ absorbance of $\mathrm{DPPH} \bullet$ in the presence of an antioxidant.

DNA binding studies

\section{Absorption titrations}

All the photophysical experiments involving interaction of the test compounds with Ct-DNA were performed in Tris- $\mathrm{HCl} / \mathrm{NaCl}$ buffer (0.01 M, pH 7.2). The absorbance of Ct-DNA in buffer at 260 and $280 \mathrm{~nm}$ gave a ratio of 1.9:1 indicating that DNA was free from protein. The concentration of DNA in stock solution was determined by UV absorption at $260 \mathrm{~nm}$ using a molar absorption coefficient $\varepsilon_{260}=6600 \mathrm{~L} \mathrm{~mol}^{-1} \mathrm{~cm}^{-1}$ (Marmur, 1961). In order to eliminate the absorbance of DNA an equal amount of DNA was added to both the reference and the test solutions. The absorption titrations were conducted at a fixed concentration of the compounds $\left(1.2 \times 10^{-4} \mathrm{M}\right)$ by varying the concentration of DNA (4.8$\left.5.7 \times 10^{-6} \mathrm{M}\right)$. Mixtures of DNA and the test solutions were allowed to incubate for $30 \mathrm{~min}$ before the absorption spectra were recorded.

\section{Fluorometric measurements}

Fluorescence spectroscopy is one of the convenient tools for examining the interaction between small molecules and nucleic acids. The relative bindings of compounds ( $\mathbf{3} \mathbf{a}$ and $\mathbf{3 b}$ ) to Ct-DNA were studied in Tris $-\mathrm{HCl} / \mathrm{NaCl}$ buffer $(\mathrm{pH}=7.2$ ). The fluoremetric experiments were carried out by maintaining the compound concentration $\left(2.6 \times 10^{-4}\right)$ as constant while varying the concentration of the DNA within the range of 3.5-5.5 $\times$ $10^{-6} \mathrm{M}$. All solutions were allowed to equilibrate thermally at $25^{\circ} \mathrm{C}$ for about $30 \mathrm{~min}$ before measurements. The emission spectra were monitored by keeping the excitation of the test compounds at $338 \mathrm{~nm}$. The emission spectra were observed at $426 \mathrm{~nm}$ for compound $3 \mathbf{a}$ and $515 \mathrm{~nm}$ for $\mathbf{3 b}$.

\section{Iodide quenching experiments}

Quenching experiments were carried out by adding increasing concentrations of potassium iodide stock solution to test compounds and test compound-DNA complex solutions, respectively. A calibration curve of the fluorescence quenching $\left(\Delta \mathrm{F}=\mathrm{F}_{0}-\mathrm{F}\right)$ versus the concentration of KI was plotted, and then the quenching constants were calculated.

\section{Viscosity measurements}

Viscosity measurements were carried out using Ostwald capillary viscometer maintained at $25 \pm 0.1^{\circ} \mathrm{C}$. Viscosity values were determined from the observed flow time of Ct-DNA containing solutions corrected from the flow time of buffer alone. The experiments were performed by varying the concentrations of the sample while fixing the DNA concentration at $6.36 \times 10^{5}$ M. Data were reported as $\left(\eta / \eta^{\circ}\right)^{1 / 3}$ versus the ratio of the concentration of the compound to Ct-DNA, where $\eta$ is the viscosity of Ct-DNA in the presence of the compound and $\eta^{\circ}$ is the viscosity of Ct-DNA alone. Relative viscosities for Ct-DNA in the presence and absence of the compounds were calculated from the relation $\eta=\left(t-t_{0}\right) / t_{0}$, where $t$ is the observed flow time of DNA containing test solution and $t_{o}$ is that of Tris$\mathrm{HCl}$ buffer alone (Aziz and Elbadawy, 2014).

\section{Circular dichroism spectral studies}

CD spectroscopy is useful optical technique for monitoring changes in DNA morphology during drugDNA interactions. CD spectra were recorded on a Chirascan CD spectropolarimeter using a rectangular quartz cuvette of path length $1 \mathrm{~cm}$. CD spectrum was obtained after averaging three scans and subtracting the buffer background. All of the experiments were performed at ambient temperature $(300 \mathrm{~K})$ in the $5 \mathrm{mM}$ phosphate buffer solution. Throughout the experiment, the $\mathrm{pH}$ of the medium was kept constant at 7.2.

\section{Thermal denaturation experiments}

UV-visible spectroscopy is an effective method for determining the melting temperature of DNA double helix. DNA melting experiments were performed by monitoring the absorbance of Ct-DNA $(25 \mathrm{mM})$ at 260 $\mathrm{nm}$ with increasing the temperature gradually from 40 to $100^{\circ} \mathrm{C}$ in absence and presence of the test compounds. The final volume of the samples was made up to $3.5 \mathrm{~mL}$ using $10 \mathrm{mM}$ Tris- $\mathrm{HCl}$ buffer ( $\mathrm{pH}$ 7.2) and the temperature of the sample was continuously monitored by means of a thermocouple attached to the sample holder. The absorbance intensities were plotted as a function of temperature, and then the Tm of DNA was determined from the midpoint of the melting curves.

\section{Molecular docking studies}

To elucidate the binding affinity and interaction mode, docking studies have been carried out on test compounds with B-DNA. The advanced molecular docking program AutoDock 4.0, which uses a powerful Lamarckian genetic algorithm (LGA) method for conformational search and docking (Morris et al., 1998) was applied for the automated molecular docking simulations. The Protein Data Bank retrieved crystal structure 
of the synthetic DNA dodecamer d(CGCGAATTCGCG) 2 (PDB ID: 1BNA). The ligands were sketched in ChemDraw Ultra 8.0 assigned with proper 2D orientation (ChemOffice package) and were converted to energy minimized 3D structures for in silico DNA docking using Auto-Dock Tools. The docking parameters including free binding energy, electrostatic energy, intermolecular energy and torsional free energy were calculated.

\section{Molecular properties prediction}

In order to evaluate the drug-like activities of synthesized compounds, the pharmacokinetic parameters such as $\log$ P, molecular weight, topological polar surface area (TPSA), hydrogen bond acceptors, hydrogen bond donors, volume and \% ABS were calculated online from Mol inspiration Chemo informatics (Table I). In addition, the rotational bond count, which indicates the flexibility of the molecule, was also calculated. TPSA was used to calculate the percentage of absorption (\% ABS) according to the equation: \% ABS $=109 \pm 0.345 x$ TPSA (Wang et al., 1997).

\section{Results and Discussion}

\section{Chemistry}

The IR spectra of title compounds were recorded in the range of $4000-400 \mathrm{~cm}^{-1}$. In the IR spectra of compounds (3a-3f) the absorption vibration frequency at about 3300 $\mathrm{cm}^{-1}$ due to amine $v\left(\mathrm{NH}_{2}\right)$ group of compound 2 disappeared. In addition, the appearance of strong absorption peak in the range of $1541-1594 \mathrm{~cm}^{-1}$ due to azomethine group indicating the formation of $-\mathrm{CH}=\mathrm{N}$ bond. All the spectra were characterized by vibrational bands in the range of $1700-1790 \mathrm{~cm}^{-1}$, due to carbonyl $v$ $(\mathrm{C}=\mathrm{O})$ vibration of the imide group. However, the band at the range $3087 \mathrm{~cm}^{-1}$ for the $3 \mathbf{a}$ were assigned to the $v$ $(-\mathrm{OH})$ group. The ${ }^{1} \mathrm{H}$ NMR spectra of the test com- pounds were recorded in DMSO- $\mathrm{d}_{6}$ at room temperature. The signal due to amine $\left(-\mathrm{NH}_{2}\right)$ group appeared as singlet at $5.09 \mathrm{ppm}$ indicates the formation of $n$ amino tetrachlorophthalimide. In ${ }^{1} \mathrm{H}$ NMR spectra of the Schiff base derivatives, this band was disappeared. Besides, the appearance of signals of azomethine group $(-\mathrm{HC}=\mathrm{N})$ in the range of 8.87-9.34 ppm confirms the formation of the proposed Schiff base framework. In the compound 3a, the signals due to ethoxy $\left(-\mathrm{OCH}_{2} \mathrm{CH}_{3}\right)$ group appeared quartet at 3.989-4.100 ppm and triplet at $1.369-1.391 \mathrm{ppm}$, while a singlet at $9.746 \mathrm{ppm}$ may be attributed to phenolic group (-OH). A signal appeared as a singlet at $3.821 \mathrm{ppm}$ for methoxy group $\left(\mathrm{OCH}_{3}\right)$ in the compound $3 \mathbf{b}$. The ${ }^{13} \mathrm{C}$ NMR spectrum of synthesized compounds exhibited characteristic signals in the range $150 \mathrm{ppm}$, which were assigned to the azomethine group corroborated well with the proposed structures. The methoxy carbon signal for $\mathbf{3 b}$ was observed at 56 ppm, while the carbonyl of 3a-3f was elucidated at 160-164 ppm. However, the signals due to methyl carbon atoms were obtained in the $20 \mathrm{ppm}$ range for compounds ( $3 \mathbf{a}$ and $3 \mathbf{c})$. The electronic spectra of compounds were recorded in the range of 200-800 $\mathrm{nm}$ in $\mathrm{N}, \mathrm{N}$-dimethyl formamide. The synthesized compounds exhibit absorption bands in the range of 230-350 nm may be assigned to $\Pi-\Pi^{*}$ energy transitions of phenyl, $\mathrm{C}=\mathrm{O}$ and $\mathrm{C}=\mathrm{N}$ functional groups.

\section{Antibacterial activity}

The in vitro evaluation of antibacterial activity was carried out to provide antibacterial efficiency of these compounds. The experimental results indicate that, four compounds are having significant activity against the selected bacteria (Table II). A comparison of antibacterial activity among all the compounds revealed that compound $\mathbf{3 b}$ was found to be very promising against E. coli and S. mutans. Compound $3 \mathbf{a}$ was found to strongly inhibit the growth of E. coli while it exhibited moderate activity against $S$. mutans. On the other hand,

\section{Table I}

Pharmacokinetic parameters important for good oral bioavailability of title compounds

\begin{tabular}{|c|c|c|c|c|c|c|c|c|c|}
\hline Compound & $\%$ ABS & $\begin{array}{l}\text { Volume } \\
\text { (A3) }\end{array}$ & $\begin{array}{l}\text { TPSA } \\
\text { (A2) }\end{array}$ & NROTB & $\begin{array}{c}\text { n-ON } \\
\text { acceptor }\end{array}$ & $\begin{array}{c}\text { n-OHNH } \\
\text { donors }\end{array}$ & $\log P$ & MW & $\begin{array}{l}\text { Lipinski's } \\
\text { violations }\end{array}$ \\
\hline $3 a$ & 81.1 & 323.1 & 80.9 & 4 & 6 & 1 & 4.5 & 448.1 & 0 \\
\hline $3 b$ & 88.1 & 298.3 & 60.7 & 3 & 5 & 0 & 4.9 & 418.1 & 0 \\
\hline $3 c$ & 91.3 & 282.3 & 51.4 & 2 & 4 & 0 & 5.3 & 402.1 & 1 \\
\hline $3 d$ & 91.3 & 286.3 & 51.4 & 2 & 4 & 0 & 5.5 & 422.5 & 1 \\
\hline $3 e$ & 91.3 & 290.7 & 51.4 & 2 & 4 & 0 & 5.6 & 466.9 & 1 \\
\hline $3 f$ & 91.3 & 263.5 & 51.4 & 2 & 4 & 0 & 4.7 & 394.1 & 0 \\
\hline Rule & - & - & - & - & $<10$ & $<5$ & $\leq 5$ & $<500$ & $\leq 1$ \\
\hline
\end{tabular}

$\%$ ABS, percentage of absorption; TPSA, topological polar surface area; NROTB, number of rotatable bonds; n-ON, number of hydrogen bond acceptors; n-OHNH, number of hydrogen bond donors; Log P, $\operatorname{logarithm}$ of compound partition coefficient between n-octanol and water; $\mathrm{MW}=$ molecular weight 


\begin{tabular}{|c|c|c|c|c|c|}
\hline \multicolumn{6}{|c|}{ Table II } \\
\hline \multicolumn{6}{|c|}{ Antibacterial and DPPH scavenging activity of the phthalimide derivatives } \\
\hline \multirow[t]{2}{*}{ Compound } & \multicolumn{2}{|c|}{ Minimum inhibition conc. $(\mathrm{mg} / \mathrm{mL})$} & \multicolumn{2}{|c|}{ Zone of inhibition (mm) } & \multirow{2}{*}{$\begin{array}{c}\mathrm{IC}_{50}(\mathrm{DPPH})(\mathrm{mg} / \\
\mathrm{mL})\end{array}$} \\
\hline & E. coli & S. mutans & E. coli & S. mutans & \\
\hline 3a & 0.065 & 0.125 & 12 & 10 & $1.1 \pm 0.06$ \\
\hline $3 b$ & 0.065 & 0.065 & 12 & 12 & $1.3 \pm 0.04$ \\
\hline $3 c$ & $>1$ & $>1$ & - & - & $1.3 \pm 0.05$ \\
\hline $3 d$ & 0.25 & 0.25 & 10 & 10 & $1.4 \pm 0.06$ \\
\hline $3 e$ & 0.25 & 0.25 & 10 & 08 & $1.4 \pm 0.04$ \\
\hline $3 f$ & $>1$ & $>1$ & - & - & $1.4 \pm 0.07$ \\
\hline Ampicillin & 0.032 & 0.032 & 20 & 18 & - \\
\hline Ascorbic acid & & & & & $0.1 \pm 0.03$ \\
\hline
\end{tabular}

compounds $\mathbf{3 d}$ and $\mathbf{3 e}$ showed less inhibition against E. coli and S. mutans. The investigation of SAR analysis of test compounds was carried out by introducing various substituents on the phenyl ring. The strongest activities against E. coli and S. mutans were observed for compound $\mathbf{3 b}$ possessing lipophilic $\mathrm{OCH}_{3}$ group. Furthermore, introduction of an additional $\mathrm{OH}$ moiety into the para position of phenyl ring, bearing an ethoxy group in meta position as noted in compound $\mathbf{3 a}$, led to increase in the antibacterial activities. However, reduction in antibacterial potency of the phthalimide derivatives ( $\mathbf{3 d}$ and $\mathbf{3 e}$ ) against $E$. coli and $S$. mutans was observed when the chlorine and bromine atoms were introduced at para position of the phenyl ring. The results obtained from SAR studies demonstrated that substituents $\left(\mathbf{R}_{\mathbf{1}}\right.$ and $\left.\mathbf{R}_{\mathbf{2}}\right)$ on the benzene ring should play an important role in governing their antibacterial activity. The higher inhibition efficiency of compound $\mathbf{3 b}$ can be explained on the basis of lipophilicity, which enhances the permeability of these compounds into the cells and inhibits further growth of the bacteria. The C-4 substitution with a methoxy group in compound $\mathbf{3 b}$ increases the electronic density of the aromatic ring, which may increase its anti-microbial activity.

\section{Antioxidant activity}

Since DPPH is a stable free radical, it has been extensively used as a tool for evaluating the free radical -scavenging activity of antioxidants. The radical scavenging capacity of title compounds was monitored by UVVis. spectrophotometer and the $\mathrm{IC}_{50}$ (concentration in $\mathrm{mg}$ required for $50 \%$ inhibition of DPPH radical) was calculated. The investigation of antioxidant assay reveals that among the screened compounds, 3a exhibited a greater activity due to the presence of phenolic group. Compound (3b) with electron donating methoxy group at para position displayed good activity whereas compounds (3c-3f) showed moderate activity due to the presence of mild electron donating groups such as methyl, chloro and bromo groups attached to the benzene ring. Based on in vitro data, compounds (3a and $3 \mathbf{b}$ ) with the highest antimicrobial and antioxidant activities were selected for in vitro DNA binding activity.

\section{DNA binding studies}

Since DNA is an important cellular receptor, development of small molecules that are capable of binding and cleaving DNA at specific sites is an interesting subject for the chemists. DNA targeting anticancer drugs basically interact with DNA through the following two modes: covalent binding and non-covalent binding. Furthermore, DNA non-covalent binding interactions can be categorized into three different modes including intercalation, groove binding and electrostatic or external surface binding. In order to understand the antibacterial activity of the phthalimide derivatives, the DNA-binding properties of the most promising compounds $\mathbf{3 a}$ and $\mathbf{3 b}$ with Ct-DNA were investigated by UV-visible, fluorescence, CD spectra, viscosity measurements and thermal denaturation studies.

\section{Absorbance measurements}

The binding potency of the compounds with DNA was investigated by UV absorption titrations. The addition of increasing amounts of Ct-DNA over a range 4.8-5.7 $\times$ $10^{-6} \mathrm{M}$ to the fixed amount of compound concentration $1.2 \times 10^{-4} \mathrm{M}$, resulted in the hyperchromic and hypsochromic shift of the absorption maxima in the UVvisible spectra of $\mathbf{3} \mathbf{a}$ and $\mathbf{3} \mathbf{b}$ (Figure 1 ). Hyperchromism and hypochromism are the spectral features that were observed during the spectrophotometric titration of compounds with Ct-DNA. Hyperchromic effect mainly arises due to the changes of DNA in its conformation and structure upon the interaction of compounds to DNA (Barton et al., 1984). However, hypochromism results from the contraction of DNA in the helix. On increasing the concentration of DNA to the test compounds, the absorption bands of the compounds (3a and $3 \mathbf{b}$ ) exhibited hyperchromism of $16.4 \%$ and $38.6 \%$ with blue shifts of $5-8 \mathrm{~nm}$ at 322 and $320 \mathrm{~nm}$, respectively (Table III). The observed hyperchromc shift 


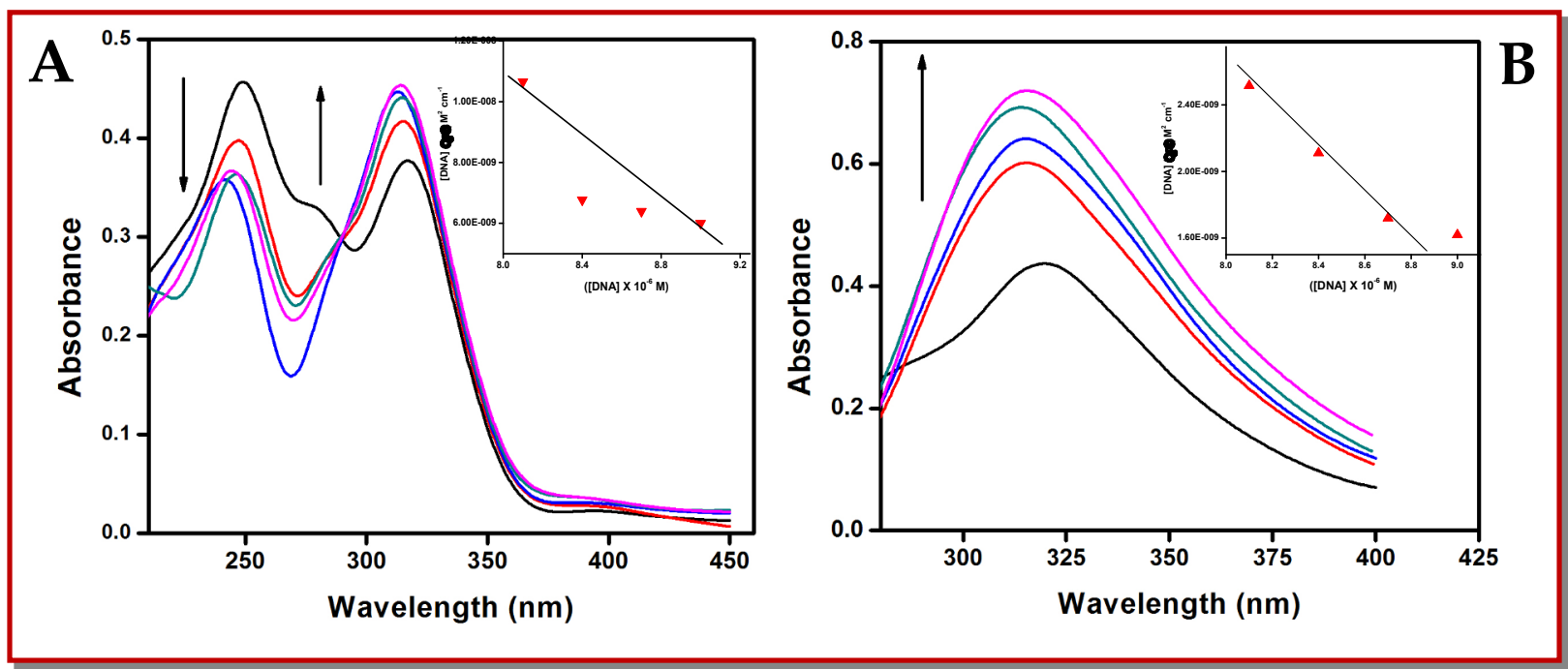

Figure 1: UV-Vis. absorption spectra of compound $\mathbf{3 a}(\mathrm{A})$ or $\mathbf{3 b}$ (B) (Black) in the presence of increasing amount of Ct-DNA. The inset is plot of DNA concentration/ $\left(\varepsilon_{a}-\varepsilon_{f}\right)$ vs DNA concentration for the titration of DNA to compound (3a)

indicated the changes in DNA structure and conformation after the compounds bound to DNA, leading to structural distortion or damage of DNA helix. In addition, the binding of compound $\mathbf{3 a}$ to $\mathrm{Ct}$ DNA led to isobestic spectral change with isobestic point at $301 \mathrm{~nm}$. The results obtained from the UV titration experiments suggest that the complex can bind to Ct-DNA.

To compare the DNA-binding strengths of these compounds, the intrinsic binding constant $K_{b}$ was calculated by using the following equation (Wolfe et al., 1987):

$$
\frac{[D N A]}{\left(\varepsilon_{a}-\varepsilon_{f}\right)}=\frac{[D N A]}{\left(\varepsilon_{b}-\varepsilon_{f}\right)}+\frac{1}{K_{b}}\left(\varepsilon_{b}-\varepsilon_{f}\right)
$$

Where, [DNA] is the concentration of DNA in base pairs, $\varepsilon_{\mathrm{a}}$ is the extinction coefficient observed for the compound at the given DNA concentration, $\varepsilon_{\mathrm{f}}$ is the extinction coefficient of the compound free in solution, and $\varepsilon_{b}$ is the extinction coefficient of the compound when fully bound to DNA. A plot of [DNA]/ $\left(\varepsilon_{a}-\varepsilon_{f}\right)$ versus [DNA] gave a slope $1 /\left(\varepsilon_{b}-\varepsilon_{f}\right)$ and $Y$ intercept equal to $1 / K_{b}\left(\varepsilon_{\mathrm{b}}-\varepsilon_{\mathrm{f}}\right)$ respectively. The intrinsic binding constant $\mathrm{K}_{\mathrm{b}}$ is the ratio of slope to intercept.

It has been observed that the $K_{b}$ value of $\mathbf{3 b}\left(1 \times 10^{5}\right)$ is slightly bigger than that of $\mathbf{3 a}\left(8 \times 10^{4}\right)$. These results thus provide strong evidence that the DNA-binding affinities of these compounds closely correlate with their antimicrobial activities.

\section{Fluoremetric measurements}

The applications of the fluoremetric technique to investigate the binding characteristics between small molecules and DNA provide a useful complement to the previously used absorption studies. The fluorescence emission spectra of test compounds in the absence and presence of DNA were studied. Upon increasing the concentration of DNA, the fluorescence intensities of $\mathbf{3} \mathbf{a}$ and $\mathbf{3} \mathbf{b}$ show an obvious decreasing trend with significant shift, which revealed that binding of these compounds to DNA indeed exists. The quenching in the luminescence of the test compounds by DNA may be attributed to the photoelectron transfer from the guanine base of DNA to the excited levels of the compounds ( $\mathrm{Xi}$ et al., 2009). The experimental results make us to suspect that the compounds may interact with DNA through the groove binding mode or external surface binding.

\section{KI quenching studies}

The KI quenching experiment was carried out to investigate the interaction mode of test compounds with DNA. Intercalative binding mode between small molecules and DNA double strands leads to protection of the entrapped molecules from an ionic quencher,

Table III

Percentage hyperchromism and hypsochromic shift of compounds ( $3 a$ and $3 b$ )

\begin{tabular}{|c|c|c|c|c|c|}
\hline \multirow[t]{2}{*}{ Compound } & \multicolumn{2}{|c|}{ Absorption band (nm) } & \multirow{2}{*}{$\begin{array}{c}\text { Hyperchromism } \\
\text { (\%) }\end{array}$} & \multirow[t]{2}{*}{ Blue shift $(\mathrm{nm})$} & \multirow[t]{2}{*}{$\mathrm{K}_{\mathrm{b}}(\mathrm{M})$} \\
\hline & Free & Bound & & & \\
\hline $3 a$ & 320 & 315 & 16.4 & 5 & $8 \times 10^{4}$ \\
\hline $3 b$ & 322 & 314 & 38.6 & 8 & $1 \times 10^{5}$ \\
\hline
\end{tabular}


thereby decrease in the fluorescent quenching (Kashanian et al., 2012). Accordingly, the magnitude of $\mathrm{K}_{\mathrm{sv}}$ of the bounded small molecules should be lower than that of the free molecules. On the other hand, in electrostatic binding and groove binding the small molecules are exposed to the quencher, which lead to the enhancement in the extent of fluorescence quenching. As a result, the magnitude of $K_{S V}$ of the bound small molecules will equal to that of the free molecules (Kumar and Asuncion, 1993). The KI quenching behaviors of the investigated compounds in the absence and presence of the Ct-DNA are shown in Figure 2. The quenching phenomenon was studied following the Stern-Volmer equation (Xu et al., 2005):

$$
F_{o} / F=1+K_{s v}[Q]
$$

Where $F_{o}$ and $F$ are the fluorescence intensities in the absence and presence of the quencher $[Q]$ and $K_{S V}$ is the Stern-Volmer quenching constant. As seen in Figure 2, the rate of KI quenching effect of bound molecules 3a $\left(K_{S V}=271.4 \mathrm{M}^{-1}\right)$ and $3 \mathbf{b}\left(K_{S V}=314.2 \mathrm{M}^{-1}\right)$ was almost equal to that of free molecules $3 a\left(K_{S V}=283.9 \mathrm{M}^{-1}\right)$ and 3b $\left(K_{S V}=341.0 \mathrm{M}^{-1}\right)$ suggesting that test compounds bound to Ct-DNA through a groove binding.

\section{Viscosity measurements}

The interaction of compounds ( $\mathbf{3} \mathbf{a}$ and $\mathbf{3 b}$ ) with Ct-DNA was also studied with the aid of viscosity measurements to find further clues about binding mode. The application of viscosity measurements of solution in DNA binding studies is one of the most useful techniques carried out in the absence of crystallographic structural data or NMR spectra. A classical intercalation causes the elongation and/or rigidification of the DNA helix in solution, leading to an increase in the specific viscosity (Sudhamani et al.,
2014). In contrast partial intercalation trend to bend or kink of the DNA helix, resulting reduction in its effective length, thereby decrease in the viscosity (Raja et al., 2005). The effects of the test compounds on the viscosity of Ct-DNA were studied. The viscosity of CtDNA was remarkably decreased upon the addition of increasing amounts of test compounds, indicating that the compounds may interact with Ct-DNA by nonintercalative mode. The decreased degree of viscosity, which may depend on its affinity to bind DNA, follows order of $3 \mathbf{b}>\mathbf{3 a}$. The results are in agreement with the similar trend of DNA binding ability as observed in case of absorption spectral studies.

\section{Circular dichroism (CD) studies}

To further investigate the interactions of compounds $\mathbf{3 a}$ and $3 \mathbf{b}$ with Ct-DNA, the CD technique was employed to observe the conformational changes in DNA. In general, the $C D$ spectrum of free Ct-DNA shows a positive band at $275 \mathrm{~nm}$, due to base stacking and a negative band at $245 \mathrm{~nm}$ due to helicity of B-DNA (Uma et al., 2005). Intercalative binding of the small molecules to the Ct-DNA affects both the positive and negative bands, as observed for classical intercalators, such as methylene blue, while the CD spectra shows little or no change in case of minor groove binding and electrostatic binding (Arjmand et al., 2012). The CD spectra of Ct-DNA (Figure 3) in the presence of test compounds at 1:1 molar ratio showed a decrease in ellipticity of both the positive and negative bands compared to only Ct-DNA. However, the change in the intensity of the negative peak is more pronounced than the change in the positive peak intensity. The result clearly reveals that both compounds $\mathbf{3 a}$ and $\mathbf{3 b}$ affect the helicity of B-DNA. Moreover, the changes induced by compound $\mathbf{3 b}$ were more significant than $\mathbf{3 a}$, which suggests that $\mathbf{3 b}$ has higher affinity for Ct-DNA. It can

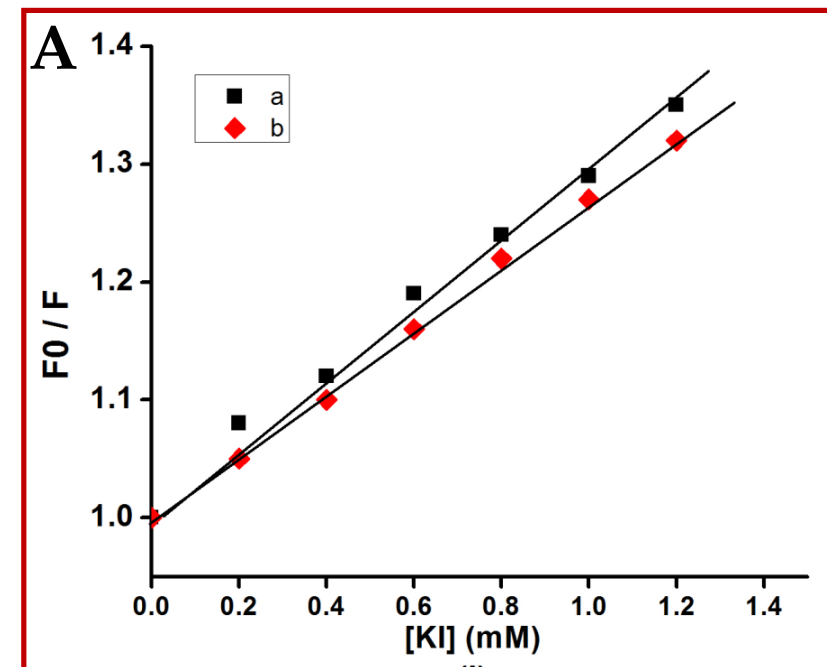

(I)

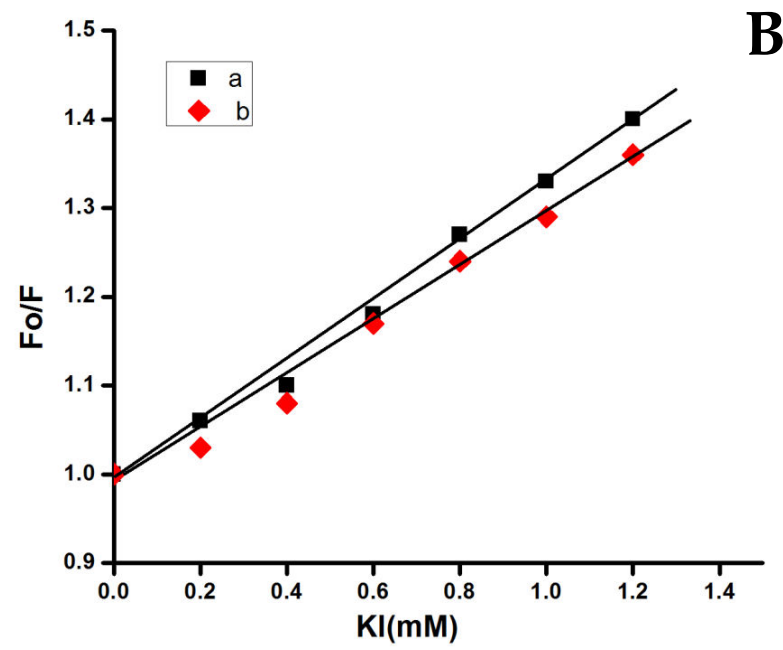

(ii)

Figure 2: Stern-Volmer quenching plots of compounds $\mathbf{3 a}$ (I) and $\mathbf{3 b}$ (II) in the (a) absence and (b) presence of Ct-DNA 


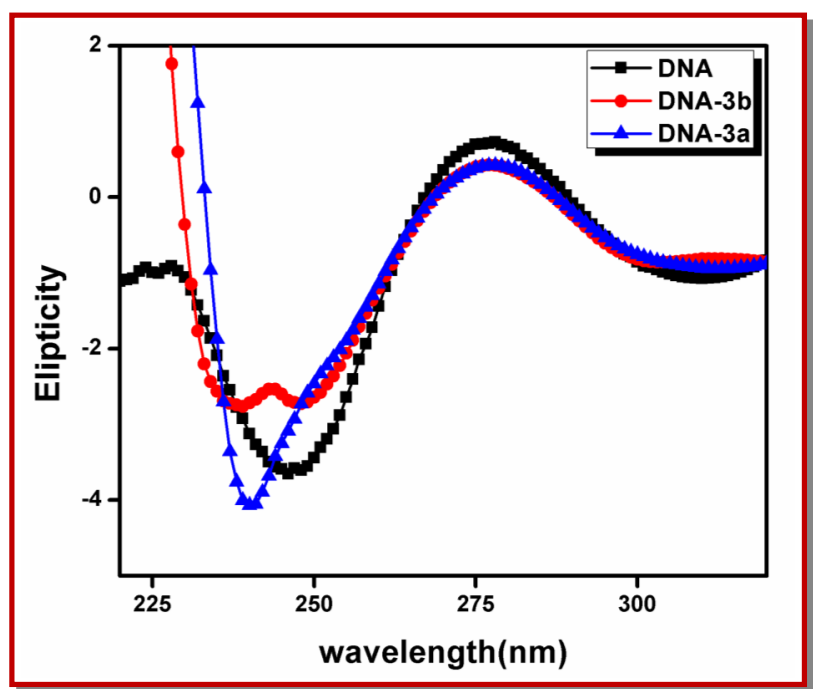

Figure 3: CD spectra of Ct-DNA $(50 \mathrm{mM})$ in the absence and presence of the compounds $\mathbf{3 a}$ and $\mathbf{3 b}(50 \mathrm{mM})$, in $5 \mathrm{mM}$ phosphate buffer

be concluded that DNA experienced a significant conformational changes upon addition of test compounds, correlated well the results obtained from UV-Vis., fluorescence spectroscopy and viscosity measurements.

\section{Thermal denaturation studies}

Further support for interaction mode of compound to DNA was obtained through thermal denaturation measurements. Upon increasing the temperature of DNA solution the double-stranded DNA gradually dissociates into single stranded. The temperature at which half of the double helix is broken into a singlestranded DNA is defined as the DNA melting temperature (Tm). In general, intercalation of small molecules between the planar bases of DNA can stabilize the DNA double helical structure thereby increases the Tm by about $5-8^{\circ} \mathrm{C}$ whereas groove binding or electrostatic binding leads to less or no significant rise in thermal denaturation temperature of DNA (Icsel and Yilmaz, 2014) The thermal denaturation profile of DNA in the absence and presence of compounds $\mathbf{3 a}$ and $\mathbf{3 b}$ were studied. The value of Tm for Ct-DNA alone was $63.5^{\circ} \mathrm{C}$, while in the presence of compounds $\mathbf{3 a}$ and $\mathbf{3 b}$, it was found to be $64.3^{\circ} \mathrm{C}$ and $64.9^{\circ} \mathrm{C}$. The $\Delta \mathrm{Tm}$ values in the range of $1-2^{\circ} \mathrm{C}$ for compounds $\mathbf{3 a}$ and $\mathbf{3 b}$ suggesting the interaction of compound with Ct-DNA. However, the moderate increase in the melting temperature of $\mathrm{Ct}$ DNA indicates the non-intercalative binding behaviour of the complex, most probably via groove binding or electro-static binding. These findings of DNA binding studies prompt us to explore the molecular docking of potent compounds $\mathbf{3 a}$ and $\mathbf{3 d}$ against B-DNA dodecamer $\mathrm{d}$ (CGCGAATTCGCG) ${ }_{2}$ which is identified to be a plausible target site for DNA binding agents.

\section{Molecular docking}

Molecular docking technique has attracted tremendous attention in the medicinal chemistry and played a crucial role in the understanding of drug-DNA interactions for design of rational chemotherapeutic drugs. The analysis of docking studies indicated that the test compounds stacked in the minor groove via hydrophobic and van der Waals interactions. In addition, compounds displayed additional stabilization through the strong intermolecular hydrogen bonding interactions with the DNA bases. As can be seen in the Figure 4, one or more H-bonds were formed between nitrogen or oxygen of phthalimide ring and nearby nucleotides. In general, small molecules bind with the minor groove, whereas large molecules prefer the major groove-binding site (Corradini et al., 2007), as the narrow shape of the former. The minimum binding energy was calculated -8.98 and $-9.23 \mathrm{kcal} / \mathrm{mol}$ for $\mathbf{3 a}$ and $\mathbf{3 b}$ respectively, indicating that the molecule $3 \mathbf{b}$ has made stronger interactions with the B-DNA than $\mathbf{3 a}$. According to the experimental data (Table IV), it is evident that $\mathbf{3 a}$ fit in the $\mathrm{C} 9 \mathrm{C} 11 / \mathrm{A} 17$ region where as $\mathbf{3 b}$

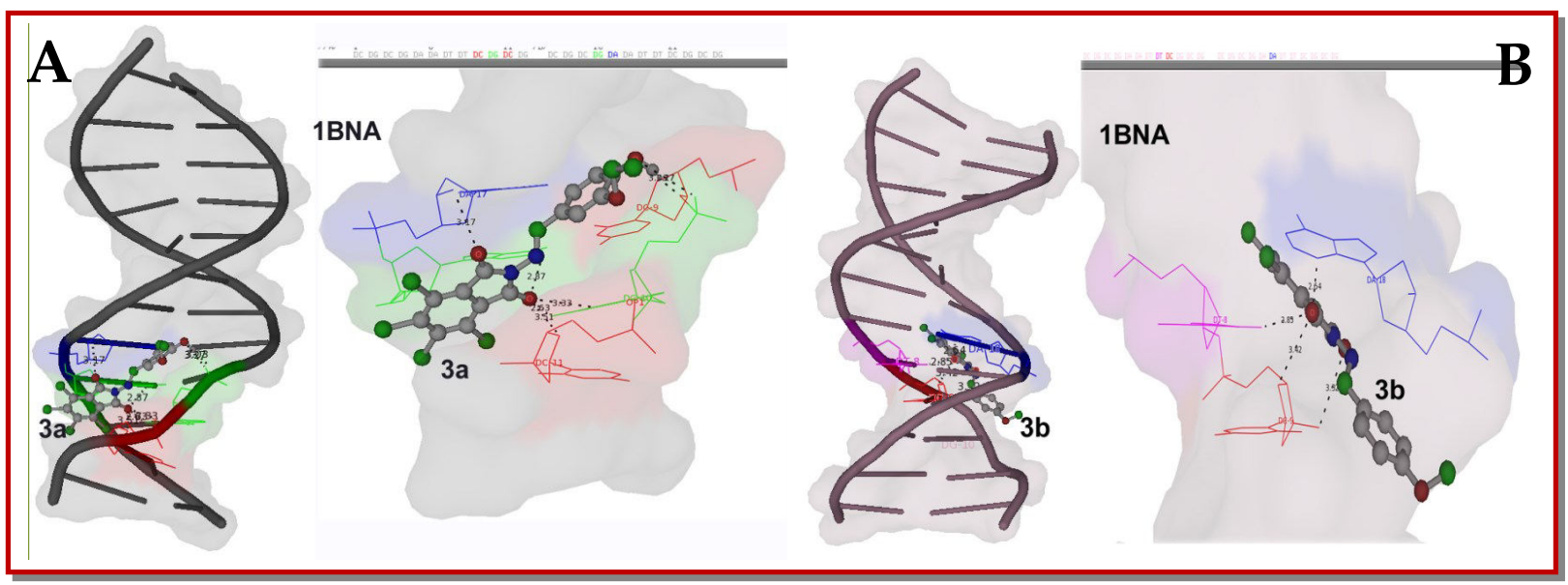

Figure 4: Molecular docked model of the most favorable binding site of compounds ( $\mathbf{3} \mathbf{a}$ and $\mathbf{3 b}$ ) with DNA dodecamer duplex of sequence d(CGCGAATTCGCG) 2 (PDB ID: 1BNA) 


\begin{tabular}{|c|c|c|c|c|c|c|c|}
\hline \multicolumn{8}{|c|}{ Table IV } \\
\hline \multicolumn{8}{|c|}{ Molecular docking parameters of $3 a$ and $3 b$ with B-DNA dodecamer duplex (PDB ID: 1BNA) } \\
\hline Compound & $\begin{array}{c}\Delta \mathrm{G} \\
(\mathrm{kcal} / \mathrm{mol})\end{array}$ & $\begin{array}{c}E_{\text {inter-mol }} \\
(\mathrm{kcal} / \mathrm{mol})\end{array}$ & $\begin{array}{c}E_{\text {elec }} \\
(\mathrm{kcal} / \mathrm{mol})\end{array}$ & $\begin{array}{c}E_{\text {torsional }} \\
(\mathrm{kcal} / \mathrm{mol})\end{array}$ & $\begin{array}{l}\text { Cluster } \\
\text { rmsd }\end{array}$ & $\begin{array}{l}\text { Reference } \\
\text { rmsd }\end{array}$ & $\begin{array}{l}\text { NB involved in bond- } \\
\text { ing }\end{array}$ \\
\hline 3a & -8.98 & -9.91 & 0.07 & 1.37 & 0.00 & 24.85 & DC-9, DC-11, DA-17 \\
\hline $3 b$ & -9.23 & -9.76 & 0.06 & 0.82 & 0.00 & 26.36 & DT-8, DC-9, DA-18 \\
\hline
\end{tabular}

fit in the T8C9/A18 region in minor groove of B-DNA and the experimental results are found to be consistent with in silico findings.

\section{Molecular properties prediction}

The Lipinski "Rule of Five" is generally used as a filter for drug-like properties which demonstrates that the molecules with good membrane permeability have log $P \leq 5$, molecular weight $\leq 500$, number of hydrogen bond acceptors $\leq 10$, and number of hydrogen bond donors $\leq 5$ (Lipinski et al., 1997). The calculated pharmacokinetic properties indicate that the synthesized compounds comply with these rules with the exception of compounds $3 \mathbf{c}-\mathbf{3} \mathbf{e}$ which possess slightly higher values for $\log \mathrm{P}$ values. The compounds $3 \mathbf{a}$ and $\mathbf{3 b}$ in this series have high number of rotatable bonds (3 -4 ) and thus, exhibit large conformational flexibility. All the synthesized compounds displayed a great \%ABS ranging from 81.09 to $91.25 \%$. Moreover, compounds are in good agreement with the acceptable range, suggesting their potential as a drug-like molecule.

\section{Conclusion}

Two compounds are showing remarkable antibacterial activity against the selected bacteria. The presence of methoxy group at para position cause compound $\mathbf{3 b}$ to be more active, which gives it a higher potential for cellular uptake, and inhibits the growth of the bacteria. The results obtained indicate that $3 b$ can bind to DNA more strongly than 3a. Interestingly, in vitro antibacterial activities of these compounds were corroborated with the DNA binding propensity of the test compounds.

\section{Acknowledgements}

The authors thank to University Grant Commission, New Delhi for financial support through Major Research Project (F. No. 41-238/2012) and Mr. Pattan S. Nayab is also thankful for UGC-BSR Fellowship. Mr. Madhusudana Pulaganti thanks to ICMR for financial support as Research Associate

\section{Conflict of Interest}

The authors confirm that this article content has no conflict of interest.

\section{References}

Abdel-Aziz AAM. Novel and versatile methodology for synthesis of cyclic imides and evaluation of their cytotoxic, DNA binding, apoptotic inducing activities and molecular modeling study. Eur J Med Chem. 2007; 42: 61426.

Al-Azzawi AM, Al-Razzak MSA. Synthesis, characterization and antimicrobial screening of new Schiff bases linked to phthalimidyl phenyl sulfonate moiety. Baghdad Sci J. 2014; 11: 438-46.

Aziz AAA, Elbadawy HA. Spectral, electrochemical, thermal, DNA binding ability, antioxidant and antibacterial studies of novel $\mathrm{Ru}$ (III) Schiff base complexes. Spectrochim Acta A. 2014; 124: 404-15.

Arjmand F, Parveen S, Mohapatra DK. Synthesis, characterization of $\mathrm{Cu}(\mathrm{II})$ and $\mathrm{Zn}$ (II) complexes of proline-glycine and proline-leucine tetrapeptides: In vitro DNA binding and cleavage studies. Inorg Chim Acta. 2012; 388: 1-10.

Bansode TN, Shelke JV, Dongre VG. Synthesis and antimicrobial activity of some new N-acyl substituted phenothiazines. Eur J Med Chem. 2009; 44: 5094-98.

Barton J K, Danishefsky AT, Goldberg JM. Tris(phenanthroline) ruthenium(II) stereo selectivity in binding to DNA. J Am Chem Soc. 1984; 106: 2172-76.

Chan CL, Lien EJ, Tokes, ZA. Synthesis, biological evaluation and quantitative structure activity relationship analysis of 2hydroxy-1H-isoindolediones as new cytostatic agents. J Med Chem. 1987; 30: 509-14.

Corradini R, Sforza S, Tedeshi T, Marchelli R. Chirality as a tool in nucleic acid recognition: Principles and relevance in biotechnology and in medicinal chemistry. Chirality 2007; 19: 269-94.

Huang SY, Zou X. Advances and challenges in protein-ligand docking. Int J Mol Sci. 2010; 11: 3016-34.

Icsel C, Yilmaz, VT. In vitro DNA binding studies of the sweetening agent saccharin and its copper(II) and zinc(II) complexes. J Photochem Photobiol B. 2014; 130: 115-21.

Kashanian S, Javanmardi S, Chitsazan A, Paknejad M, Omidfar K. Fluorometric study of fluoxetine DNA binding. J Photoch Photobio. 2012; 113: 1-6.

Kumar CV, Asuncion EH. DNA binding studies and site selective fluorescence sensitization of an anthryl probe. J Am Chem Soc. 1993; 115: 8547-53.

Lima LM, Castro P, Machado AL, Fraga CAM, Lugnier C, 
Moraes VLG, Barreiro E J. Synthesis and anti-inflammatory activity of phthalimide derivatives, designed as new thalidomide analogues. Bioorg Med Chem. 2002; 10: 3067-73.

Lipinski CA, Lombardo F, Dominy BW, Feeney PJ. Experimental and computational approaches to estimate solubility and permeability in drug discovery and development setting. Adv Drug Delivery Rev. 1997; 23: 3-25.

Marmur J. A procedure for the isolation of deoxyribonucleic acid from microorganisms. J Mol Biol.1961; 3: 208-18.

Miliauskas G, Venskutonis PR, Van Beek TA. Screening of radical scavenging activity of some medicinal and aromatic plant extracts. Food Chem. 2004; 85: 231-37.

Morris GM, Goodsell DS, Halliday RS, Huey R, Hart WE, Belew RK, Olson AJ. Automated docking using a Lamarckian genetic algorithm and an empirical binding free energy function. J Comput Chem. 1998; 19: 1639-62.

Nayab PS, Arif R, Arshad M, Rahisuddin. Synthesis, characterization, antibacterial, DNA binding and molecular docking studies of novel N-substituted phthalimides. Heterocyclic Lett. 2015; 5: 223-39.

Raja A, Rajendiran V, Maheswari PU, Balamurugan R, Kilner CA, Halcrow MA, Palaniandavar M. Copper(II) complex of tridentate pyridyl methylethylinediamines: Role of ligand steric hindrance on DNA binding and cleavage. J Inorg Biochem. 2005; 99: 1717-32.

Shukla S, Srivastava RS, Shrivastava SK, Sodhi A, Kumar P. Synthesis, characterization, in vitro anticancer activity, and docking of Schiff bases of 4-amino-1,2-naphthoquinone. Med Chem Res. 2013; 22: 1604-17.

Sudhamani CN, Naik HSB, Girija D, Gowda KRS, Giridhar M,
Arvinda T. Novel complexes of $\mathrm{Co}(\mathrm{III})$ and $\mathrm{Ni}(\mathrm{II})$ containing peptide ligands: Synthesis, DNA binding and photonuclease activity. Spectrochimica Acta Part A. 2014; 118: 271-78.

Tumer M, Deligonul N, Golcu A, Akgun E, Dolaz M, Demirelli H, Digrak M. Mixed-ligand copper(II) complexes: Investigation of their spectroscopic, catalysis, antimicrobial and potentiometric properties. Trans Met Chem. 2006; 31: 112.

Tumer M, Koksal H, Serin S, Digrak M. Antimicrobial activity studies of mononuclear and binuclear mixed-ligand copper (II) complexes derived from Schiff base ligands and 1,10phenanthroline. Trans Met Chem. 1999; 24: 13-17.

Uma V, Kanthimathi M, Weyhermuller T, Nair BU. Oxidative DNA cleavage mediated by a new copper(II) terpyridine complex: Crystal structure and DNA binding studies. J Inorg Biochem. 2005; 99: 2299-307.

Wang RX, Fu Y, Lai L. A new atom-additive method for calculating partition coefficients. J Chem Inf Comput Sci. 1997; 37: 615-21.

Wolfe A, Shimer GH, Meehan T. Polycyclic aromatic hydrocarbons physically intercalate into duplex regions of denatured DNA. Biochem. 1987; 26: 6392-96.

Xi P, Xu Z, Chen F, Zeng Z, Zhang X. Study on synthesis, structure, and DNA-binding of $\mathrm{Ni}, \mathrm{Zn}$ complexes with 2phenylquinoline-4-carboylhydrazide. J Inorg Biochem. 2009; 103: $210-18$.

$\mathrm{Xu} \mathrm{Z}$, Bai G, Dong C. Studies on interaction of an intramolecular charge transfer fluorescence probe: 40Dimethylamino-2,5-dihydroxychalcone with DNA. Bioorg Med Chem. 2005; 13: 5694-99.

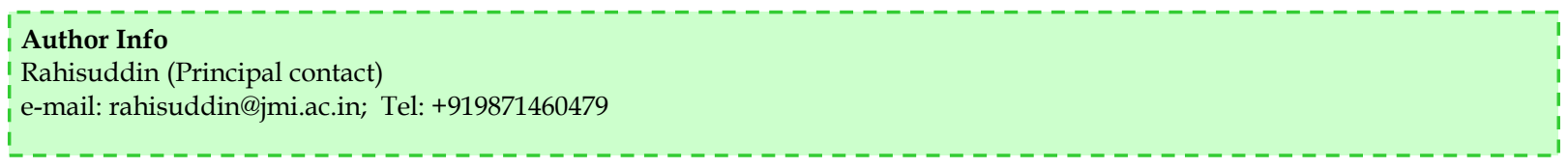

